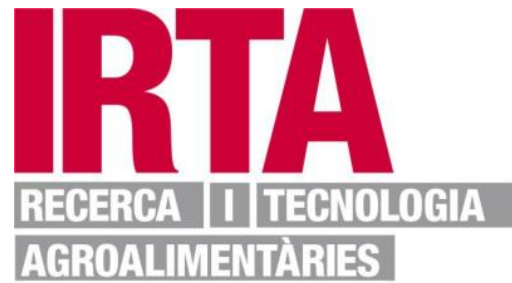

This is the peer reviewed version of the following article: Ait Sidhoum, Amer, and Teresa Serra. 2017. "Corporate Sustainable Development. Revisiting The Relationship Between Corporate Social Responsibility Dimensions". Sustainable Development 26 (4): 365-378. Wiley, which has been published in final form at https://doi.org/10.1002/sd.1711. This article may be used for non-commercial purposes in accordance with Wiley Terms and Conditions for Use of Self-Archived Versions 


\title{
Corporate sustainable development. Revisiting the relationship between corporate social responsibility dimensions.
}

\author{
Amer Ait Sidhoum ${ }^{1}$ \\ Centre de Recerca en Economia i Desenvolupament Agroalimentaris (CREDA)-UPC-IRTA, Parc Mediterrani de la \\ Tecnologia, Edifici ESAB, C/Esteve Terrades, 8, 08860 Castelldefels, Barcelona, Spain. \\ Email: amer.ait-sidhoum@upc.edu

\section{Teresa Serra} \\ Department of Agricultural and Consumer Economics, University of Illinois, 335 Mumford Hall, 1301 W Gregory \\ Drive, Urbana, IL 61801, United States. Email: tserra@illinois.edu
}

\begin{abstract}
With rising stakeholder concerns over sustainable development, Corporate Social Responsibility (CSR) has become key for the business community, moving the business model beyond financial performance to a new voluntary paradigm based on natural resources conservation, social welfare, stakeholder engagement and economic performance. This article aims to answer whether profitable business is compatible with balanced sustainability by investigating the relationship between the economic, social, environmental and governance performance for a sample of global firms. A Canonical Vine (C-Vine) copula is used for this purpose. Results show the existence of a fairly strong positive relationship between economic, social and environmental performance. The corporate governance dimension is shown to have a weak relationship with the rest of CSR dimensions. Important policy implications are derived from these results.
\end{abstract}

Keywords: Firm Sustainability; Sustainable Development; Corporate Social Responsibility; Environmental Preservation; Social Welfare.

\footnotetext{
${ }^{1}$ Corresponding author: Amer Ait Sidhoum, Tel: (+34) 935-521-209, Fax: (+34) 935-521-121.

Email: amer.ait-sidhoum@upc.edu
} 
With rising stakeholder concerns over sustainable development, firms have been increasingly called upon to take responsibility for their impacts on societies and the environment. As a result, many businesses have implemented sustainable practices that include environmental and social concerns into business operations (D'amato et al., 2009). Firms have also changed the way they interact with stakeholders, by devoting higher efforts to defining rules and practices to better balance their different interests. The new business paradigm involves expansion of firms' commitments beyond their financial obligations to deliver both private and public goods. Changes in the business model have also involved a fundamental change in business performance measurement, that has moved beyond financial indicators to embrace environmental, social and governance barometers. New performance measurements reflect the fact that a corporation's economic prosperity in isolation from social and environmental issues is no longer acceptable.

The term Corporate Social Responsibility (CSR) was coined to describe corporate selfregulation integrated into a business model comprising the many dimensions of corporate activities (Perrini \& Tencati, 2006). The literature has proposed different definitions of CSR. These range from very limited views of the concept, to more comprehensive conceptualizations. In any case, the concept remains imprecise at best and fuzzy at worst. From the perspective of Matten \& Crane (2005), CSR embraces the responsibility to be profitable, to obey the law, a philanthropic responsibility and an ethical responsibility to society to do what it is right. According to the United Nations Industrial Development Organization (UNIDO, 2015), CSR "is a management concept whereby companies integrate social and environmental concerns in their business operations and interactions with their stakeholders. CSR is generally understood as being the way through which a company achieves a balance of economic, environmental and social imperatives ("TripleBottom-Line- Approach"), while at the same time addressing the expectations of shareholders and 
stakeholders." CSR can bring an array of competitive advantages to the firm such as increased profits, better access to capital and markets, enhanced firm reputation and brand image, higher customer loyalty, etc. Skeptics argue that a significant redefinition of the role of businesses can be dangerous to the firm's financial well-being (Walley \& Whitehead, 1994).

The relationship between financial performance and CSR is not well established. While several studies have tried to shed light on this question, results have been inconclusive (Margolis $\&$ Walsh, 2003; Vogel, 2005). Some authors conclude that a positive relationship exists between firm social responsibility and firm economic performance (Oeyono et al., 2011; Van Beurden \& Gössling, 2008; Veronica Siregar \& Bachtiar, 2010), while others find a negative or null correlation (Lima Crisóstomo et al., 2011; Smith et al., 2007; S. H. Teoh et al., 1999; Wright \& Ferris, 1997) Some researchers (Alafi \& Hasoneh, 2012; Galbreath \& Shum, 2012; Griffin \& Mahon, 1997; Margolis \& Walsh, 2003; H. Y. Teoh et al., 1998) question the common approach of assessing the direct link between social responsibility and financial performance, while ignoring the role of other intervening factors, which may lead to misleading results.

Our article aims at shedding light on this debate by answering whether profitable business is compatible with balanced sustainability by investigating the relationship between the four CSR dimensions for a sample of global firms. A Canonical Vine (C-Vine) copula is used for this purpose, which represents a novel approach to model dependencies. Conventional analyses of dependency between multiple random variables are constrained by the availability of statistical tools and mainly rely on multivariate normal or student's $t$ distributions. These distributions have been shown to usually misrepresent the data studied due to the presence of kurtosis, skewness and non-normality. Further, dependency between variables may be stronger in the tails of the distribution than in the center, and be characterized by asymmetries. For example, a firm may 
invest more intensively in environmentally friendly processes when its financial results are in the upper quartile of the distribution than when they are in the lower quartile. This reinforces the call for flexible statistical instruments (Barnett \& Salomon, 2006, 2012). We use statistical copulas for such purpose. More specifically, dependence between four CSR dimensions (economic, environmental, social and corporate governance) is assessed through a Canonical Vine copula model (C-Vine). An obstacle to the analysis is the lack of comparable firm-level data on the different dimensions of CSR. We base our research on a dataset that provides firm financial metrics for a sample of global firms, as well as comparable and auditable information on environmental, social and corporate governance performance, that allows application of quantitative methods.

\section{Literature review}

CSR activities aim at promoting business practices that are compatible with sustainable development (Moon, 2007; Baumgartner, 2014; Gelbmann, 2010; Shah et al., 2016; Stewart \& Gapp, 2014) Through CSR a business commits to four main responsibilities in decreasing order of priority: the economic, the legal, the ethical, and the philanthropic. The rationale behind this prioritization is that if a firm goes out of business, it will be unable to sustain the other obligations, including the philanthropic ones (Brusseau, 2011; Chang \& Kuo, 2008). Consistently, Vogel (2005) emphasizes the need to better understand the relationship between CSR and firm financial performance.

The debate on this relationship is still relevant (Esteban-Sanchez et al., 2017; Q. Wang et al., 2016) and the nature of the relationship still ambiguous. In what follows, we provide an overview of the literature that, using firm-level data, studies the links between economic, environmental, social and governance dimensions of CSR. Margolis et al. (2009) perform a meta- 
analysis by using 251 studies from 1972 to 2007 and conclude there is an overall positive (though small) relationship between CSR and firm financial performance. By using data of Japanese manufacturing firms from 2004 to 2008, Iwata \& Okada (2011) consider the link between firm financial outcomes and two different environmental issues: waste and greenhouse gas emissions. The methodological approach is based on linear regression analysis. While waste is not found to have significant effects on financial outcomes, a reduction in greenhouse gas emissions improves them.

Molina- Azorín et al. (2009) examine 32 articles that analyze the influence of environmental management on financial performance. They find a predominance of the studies reporting a positive impact. By using structural-equation modeling, López-Gamero et al. (2009) show that the effect of environmental protection on firm performance is positive. Muhammad et al. (2015) use a linear regression analysis to study the link between environmental and financial outcomes of publicly listed companies in Australia, in periods of growth and contraction. They find a strong positive association between the two variables during the pre-financial crisis period (2001-2007) and no relationship during the financial crisis (2008-2010).

Several studies have not arrived to such optimistic conclusions regarding the impacts of environmentally friendly processes on economic results. Horváthová (2010) examines dependency between environmental and financial outcomes through a meta-regression analysis of 64 outcomes from 37 empirical studies. Results show a negative link between environmental and financial results that significantly increases when using simple correlation coefficients, relative to more advanced methodologies. Wagner et al. (2002) examine the relationship between the environmental and economic performance of firms in the European paper manufacturing industry. Findings predict the relationship to be uniformly negative. The methodological approach is based 
on a simultaneous equations system that allows for the mutual dependence of the two CSR dimensions considered.

Galema et al. (2008) use regressions to assess the impact of different dimensions of socially responsible performance on firm values. Soana (2011) uses Pearson correlation coefficients, in order to investigate the connection between social and financial performance in the Italian banking sector. None of these studies finds a statistically significant relationship between social performance and financial outcomes. Statman \& Glushkov (2009) analyze a sample of firms that conduct CSR activities and, using descriptive statistics, find that their stocks yield higher returns than conventional companies' stocks.

Some studies indicate that firms that invest in stakeholder engagement and management have a positive image within the community, enabling them to recruit and retain high quality employees(Cerin \& Reynisson, 2010; Humphrey et al., 2012; Lado \& Wilson, 1994; Waddock \& Graves, 1997). Proponents further argue that better-governed firms are relatively more profitable, more valuable, and pay out more cash to their shareholders (Andreou et al., 2014; Brown \& Caylor, 2004). The literature suggests that good corporate reputation is important, not only because it is a precursor of value creation, but also because it is intangible, which makes imitation very difficult for the concurrent companies (S. J. Brammer \& Pavelin, 2006; Eberl \& Schwaiger, 2005; Roberts \& Dowling, 2002). A strong and positive correlation has been observed between having been listed in one or more popular business magazines and corporate financial performance (Filbeck et al., 2009a, 2013). Nollet et al. (2016) studied the relationship between corporate social and governance performance and financial outcomes, using Bloomberg's Environmental Social Governance (ESG) Disclosure scores, covering the S\&P500 firms in the period 2007-2011. Their analysis allows for linear and nonlinear relationships. Results show that a nonlinear relationship characterizes the link 
between corporate governance and financial results. Gupta \& Sharma (2014) conduct a descriptive analysis of Indian and South Korean firms with the aim of assessing the effects of corporate governance on their economic performance. They find corporate governance practices to have limited impact on firms' financial performance and firm share prices.

As shown by the literature review presented above, previous research has usually considered the links between an incomplete set of the different dimensions of CSR. Further, lack of comparable data across firms and dimensions, has limited the type of study that can be conducted. Our analysis uses a dataset that comprises a wide range of global firms and covers the four main pillars of CSR (economic, environmental, social and governance). We thus make a comprehensive assessment of the interactions of the different CSR dimensions. The methodological approach represents a contribution to a literature that has mainly relied on linear regression and correlations to infer the relationship between CSR components. ${ }^{2}$ Previous regression studies often involve endogeneity issues that are not always acknowledged and addressed. This may lead to imprecise and distorted parameter estimation (Hamilton \& Nickerson, 2003; Crane et al., 2017). Garcia-Castro, Ariño, \& Canela (2010) have shown how some results may change or even may be reversed when endogeneity is appropriately modeled. Further, both linear regression and linear correlation methods may be misleading if dependencies are characterized by nonlinearities (Manasakis et al., 2014; Nollet et al., 2016). The copula approach adopted in our article does not rely on endogeneity-exogeneity assumptions and allows for nonlinear relationships.

\footnotetext{
${ }^{2}$ Some late articles on the topic propose a nonlinear framework (Flammer, 2015; Garcia-Gallego \& Georgantzis, 2009; Manasakis et al., 2013).
} 


\section{Methodology}

Given the contradicting conclusions that previous literature has reached about the links between the different CSR dimensions, our objective is to contribute to this debate. By using a sample of global firms, we identify the dependence between firm economic, environmental, social and corporate governance performance. Since we are interested in using methodological approaches that impose little restrictions on the dependency structure, we base our analysis on statistical copulas (Joe, 1996 and Nelsen, 2006).

Copulas can be seen as a more sophisticated tool than linear correlation to explain dependence between variables. Copulas offer two main advantages relative to correlation analysis. First, unlike correlation analysis, copula functions do not require assuming multivariate normality, which does not usually hold in empirical data. Second, copulas are more flexible than correlation analysis, as they allow for nonlinearities such as dependence measures that changes across the distribution.

More formally, copulas are defined as a flexible tool that allows for the characterization of the dependence structure between random variables and are especially useful if no obvious choice for the multivariate density function exists. The use of copulas in the economics literature is rather recent and most empirical applications are found within the financial economics literature (Patton, 2004; Patton, 2006). Copula models are based upon the Sklar's theorem (1959) that establishes that a multivariate dependence structure can be separated from the univariate margins. Let $F_{1}$ and $F_{2}$ be two univariate continuous distribution functions of two random variables $\left(x_{1}, x_{2}\right)$. The copula of $\left(x_{1}, x_{2}\right)$ is the joint distribution function of $u_{1}=F_{1}\left(x_{1}\right)$ and $u_{2}=F_{2}\left(x_{2}\right)$, where $u_{1}$ and $u_{2}$ are the probability integral transforms of $x_{1}$ and $x_{2}$ that are distributed as Uniform $(0,1)$. According to the Sklar theorem, there exists a unique copula $C$ that can be expressed as: 
$H\left(x_{1}, x_{2}\right)=C\left(F_{1}\left(x_{1}\right), F_{2}\left(x_{2}\right)\right)=C\left(u_{1}, u_{2}\right)$,

where $C\left(u_{1}, u_{2}\right)$ is a bivariate distribution function with marginal distributions $F_{1}$ and $F_{2}$. The joint bivariate density function can be expressed as:

$h\left(x_{1}, x_{2}\right)=c\left(F_{1}\left(x_{1}\right), F_{2}\left(x_{2}\right)\right) f_{1}\left(x_{1}\right) f_{2}\left(x_{2}\right)$,

where $c$ is the copula density and $f_{1}\left(x_{1}\right)$ and $f_{2}\left(x_{2}\right)$ are univariate density functions.

While copulas allow the researcher to focus on modeling univariate distribution functions and this usually leads to better models (Patton, 2006), care has to be taken when modeling the dependence between more than two variables. For the bivariate case, a wealthy range of well studied copulas exists (Joe, 1997; Nelsen, 2006). In contrast, despite the wide array of bivariate copulas, there is a very limited number of higher dimensional models.

Vine copulas are specially recommended in multivariate settings. They consist of multivariate graphical models based on bivariate copulas, also called pair-copulas, where each pair-copula can be chosen independently from the other pairs, which confers the vine models great flexibility in modeling dependencies. They were introduced by Joe (1997) and further developed by Bedford \& Cooke (2001, 2002) and Kurowicka \& Cooke (2006). As bivariate copulas, vine models also allow separating marginals in dependence modeling.

Vines are integrated by trees (known as regular vines) that are built based on pair copulas. Regular vines are however too general and embrace a high number of possible copula decompositions. Aas et al. (2009) popularized two subclasses of regular vines: canonical vines (C- 
vines) and drawable vines (D-vines) (Kurowicka, D. and Cooke, 2004). D-vines are useful for variables that have a temporal order known a priori (Zimmer, 2015), whereas canonical vines are appropriate when there is a natural order of importance, i.e., when a particular variable is known to be a key variable that governs interactions in the data set. In such a situation, one may decide to locate this variable at the root of the canonical vine (Aas et al., 2009). We select a C-vine copula, under the assumption that economic performance is the most relevant CSR dimension for our sample of global firms. For example, firms may go greener to either increase their margins by reducing their costs, or to increase their market share by offering more attractive products that respond to increasing consumer awareness on environmental issues. More generally, firms investing in CSR usually pursue brand, trust and reputation, as well as consumer loyalty that may reduce demand elasticity and allow charging higher prices (Bhattacharya \& Sen, 2003; Elfenbein \& McManus, 2010; Starks, 2009). In the same way, improving corporate governance structures may increase market and investor confidence (Azam et al., 2011). All this may eventually lead to improved financial performance.

Figure 1 shows a C-vine measuring dependence between the four CSR pillars: economic (ECN), environmental (ENV), social (SOC) and governance (GOV). The C-vine consists of three trees $T_{j}, j=1, \ldots 3$ with a unique node that is connected to $n-j$ edges, where " $n$ " is the number of variables in the model. The first $\mathrm{C}$-vine tree measures dependence with respect to the first root node, using bivariate copulas for each pair. Conditional on this variable, pairwise dependencies with respect to a second root node are modeled. A root node is chosen for each tree and all pairwise dependencies with respect to this node are modeled, conditioned on all previous root nodes (Brechmann et al., 2013). 


\section{Insert Figure 1 here}

C-vines entail a variable ordering with a sequentially decreasing driving force as we move from the first to the last tree. The n-dimensional density corresponding to a $\mathrm{C}$-vine is given by:

$$
f(x)=\prod_{k=1}^{n} f_{k}\left(x_{k}\right) \prod_{j=1}^{n-1} \prod_{i=1}^{n-j} c_{j, j+i \mid 1, \ldots, j-1}\left(F\left(x_{j} \mid x_{1}, \ldots, x_{j-1}\right), F\left(x_{j+i} \mid x_{1}, \ldots, x_{j-1}\right)\right)
$$

where $f_{k}, k=1, \ldots, n$ denote the marginal densities and $c_{j, j+1 \mid 1, \ldots, j-1}$ bivariate copula densities. In the following lines, a description of the specification and estimation process of $\mathrm{C}$-vines is offered. In order to measure bivariate dependence, we consider the most popular and most widely used copulas: the Gaussian and the Student's t, that belong to the class of Elliptical copulas. Archimedean copulas are another no less important class of copulas that we consider. Within this group, we consider single-parameter copulas such as Clayton, Gumbel and Frank copulas, as well as the two-parameter families introduced by Joe (1997) named BB1 (Clayton, Gumbel) and BB7 (Joe-Clayton), which allow for lower and upper tail dependence simultaneously. Table 1 below shows the properties usually considered to characterize the different types of copulas, i.e., whether they can measure positive and negative dependence, asymmetric tail dependence or upper or lower tail dependence. From the copula classes mentioned above, we choose the most appropriate copula for each pair of CSR indicators.

Insert Table 1 here 
The use of information criteria such as the Akaike Information Criterion (AIC) or the Bayesian Information Criterion (BIC) (Joe, 1997) allows automation of the bivariate copula selection process by chosing the model with the smallest information criteria. Clarke (2007) and Vuong (1989) tests constitute alternative likelihood ratio specification tests that compare across copulas. Based on Vuong (1989) and Clarke (2007), Belgorodski (2010) provides a selection test for bivariate copulas. The test compares a bivariate copula $C_{0}$ to all other possible bivariate copula models taken into account, in order to determine which family fits the data best. If a copula $C_{0}$ is favored over another copula, it gets a score of +1 . A score of -1 is assigned if the other copula is identified to be better. The total score is the sum of the scores from all pairwise comparisons and the model with the highest score should be chosen.

Each stage of the estimation process not only entails selection of the copula family, but the root variable as well. While our C-vine copula is based on the assumption that the economic performance constitutes the root of the first vine tree, the ordering of the remaining variables is less clear. As a result, the following six possible orderings are considered and comparison among them is based on the Vuong (1989) and Clarke (2007) tests: ECN-ENV-SOC-GOV (M1 model), ECN-SOC-ENV-GVN (M2); ECN-ENV-GVN-SOC (M3); ECN-SOC-GVN-ENV (M4); ECNGVN-ENV-SOC (M5); ECN-GVN-SOC-ENV (M6). Once the ordering is established, the C-vine is estimated by ML techniques (Aas et al., 2009; Czado et al., 2012) . The log-likelihood is given by (4).

$\sum_{t=1}^{T} \sum_{i=1}^{n-j} \sum_{i=1}^{n-j} \log \left(c_{j, j+i \mid 1, \ldots, j-1}\left(F\left(x_{j, t} \mid x_{1, t}, \ldots, x_{j-1, t}\right), F\left(x_{j+i, t}, \ldots, x_{j-1, t}\right)\right)\right)$.

In the following section we present details on the data used and the research results. 


\section{Research results}

Socially responsible activities are an important part of the overall corporate performance in the modern world. While the impacts of CSR are not well known, several articles have attributed many advantages to CSR including, but not limited to, managerial benefits (Brammer \& Millington, 2008) better product marketing (Fombrun, 1996), improved financial performance (Kansal et al., 2014; Lin et al., 2009), or employee retention (Greening \& Turban, 2000).

Over the past two decades, investors have become increasingly interested in CSR data, as they realize the influence of CSR on firms' long-term performance. This has increased firm disclosure of environmental, social and corporate governance data. Disclosure, however, is not standardized as companies usually report in different formats, units, scope, etc. As a result, datasets

offering comparable firm-level extra-financial information are limited. Our research uses data from the 2012 ASSET4 ESG ${ }^{\text {http://financial.thomsonreuters.com/en/products/data-analytics/company-data/esg-research-data.html }}$ dataset from Thomson Reuters, which is considered a leader in providing structured and standardized ESG research data (Collison, Cobb, Power, \& Stevenson, 2008; Filbeck, Gorman, \& Zhao, 2009) . The ASSET4 dataset, which has already been used in the literature (Ferrero-Ferrero, Fernández-Izquierdo, \& Muñoz-Torres, 2015; Rivera, Muñoz, \& Moneva, 2017), provides extrafinancial information that is transparent, objective and comparable across companies and that is auditable (Schäfer et al., 2006) . Based on the definition and collection of over 250 key performance indicators, ASSET4 measures firm performance in the four main CSR pillars: economic, environmental, social and governance. We choose ASSET4 ESG dataset for several reasons. In the first place, ASSET4 is a global firm dataset that includes more than 4000 firms in more than 50 global markets, and thus offers a substantial amount of data. Along with ASSET4, 
MSCI's Kinder, Lydenberg, Domini Research \& Analytics (KLD) is one of the larger providers of CSR information (Eding \& Scholtens, 2017). However, Chatterji, Levine, \& Toffel (2009) found evidence that KLD's ratings are not optimally using publicly available data. Along the same lines, Ziegler, Busch, \& Hoffmann (2009) claim that data from Innovest Strategic Value Advisors and KLD include highly subjective elements. Another ASSET4 advantage is that it also contains economic data, which makes the dataset suitable for studies examining the relationship between CSR and economic performance (Ioannou \& Serafeim, 2012).

ASSET4 environmental (ENV) performance score is built based on the firm reduction of resource use; emission reduction; and product innovation. The social (SOC) score is based on indicators of employment quality; health and safety; training and development; diversity; human rights; community; and product responsibility. The corporate governance (GOV) indicator is developed based on information on board structure; compensation policy; board functions; shareholder's rights; vision and strategy. Finally, the economic (ECN) performance score is founded on client loyalty; financial performance; and shareholders' loyalty. The performance indicators are equally weighted computations of the relative performance of the firm, being the benchmark the ASSET4 universe. Ratings are then z-scored and normalized so that the score lies between 0 and $100 \%$. ASSET4 is strictly built on publicly available information, including firm sustainability reports, company websites, annual reports, proxy filings, news of major providers, as well as NGOs, and the Carbon Disclosure Project (Thomson Reuters, 2013). We analyze the relationship that exists between the four CSR performance scores of 2,728 corporate firms in 2012. While the dataset comprises around 4,000 firms, we exclude those with missing values in any of the performance indicators considered. 
Table 2 shows the descriptive statistics for the economic, environmental, social and corporate governance scores. Our dataset is heterogeneous, containing firms from different economic sectors. A distribution of firms across sectors is presented in Table 3 below. The table shows that more than half of sample firms belong to the financial, industrial and consumer cyclicals sectors. As a result, each of the ESG pillars is built based on rather heterogeneous data. While some firms strongly pollute the air, other production activities have a stronger impact on water streams. As noted above, the methodology used by ASSET4 allows comparison of the ratings across different firms. In spite of the heterogeneity embedded in the sample, standard deviations in Table 2 do not indicate a very high variability in performance scores. All four scores fluctuate around $50 \%$, with the environmental and social scores being on the order of $57 \%$, followed by the governance score of 55\%, and the economic score of almost 50\% (Table 2). The skewness and kurtosis values suggest that our data have flatter distributions relative to the normal. Distributions are further asymmetric with a long tail to the left. The Jarque-Bera and Kolmogrov-Smirnov tests confirm the non-normality of the four scores used (at the 5\% significance level).

Insert Table $2 \& 3$ here

In Figure 2, we present contour plots with standard normal margins below the diagonal and scatter plots above. Visual analysis suggests significant dependence between economic, environmental and social performance indicators. The environmental-social pair appears to display the strongest correlation, with tail dependencies especially on the lower (left) part. Conversely, governance scores are clearly less correlated with the other performance scores. 


\section{Insert Figure 2 here}

Table 4 shows the results of the C-vine copula M1 model estimation. Table 5 presents the Vuong (1989) and Clarke (2007) goodness of fit tests of our selected C-vine model (M1) against the other five alternatives (M2 to M6). The p-values corresponding to the Vuong test indicate that M1 is preferred to M2 and M4, and equally valid against the alternatives M3, M5 and M6. Clarke test results support selection of model M1 against all possible alternatives. The information criteria and goodness-of-fit test scores for the bivariate copulas are presented in Table 6. For each bivariate copula, we first present the scores assigned to copulas according to Belgorodski (2010), i.e., the bigger the value, the better the copula fit. The, we present AIC and SBC criteria that decline with the increase in the goodness of fit. We mark in bold the best copula according to these criteria. Since different copula families have different parameters that are not directly comparable, we measure the strength of dependence involved by each copula through the corresponding Kendall's $\tau$ value, which focuses on the central area of the bivariate distribution, as well as the lower and upper tail dependencies $\left(\lambda_{L}, \lambda_{U}\right)$ that measure dependency at the extremes of the distribution (Table 4). Hence, while columns four and five in Table 4 contain the values of the bivariate copula parameters, columns six to eight contain comparable dependence measures that increase with the strength of dependence.

Insert Table 4, 5 \& 6 here

Results from table 4 show that, according to the Frank copula, which is found to best represent dependency between economic and environmental and social outcomes, firms with better 
economic results, usually stand out as firms with better social (with a Kendall's $\tau$ of 0.5 ) and environmental performance $(\tau=0.42)$. The BB1 copula, that quantifies the links between economic and governance performance, shows a Kendall's $\tau$ on the order of 0.24 , suggesting a substantially lower degree of dependence between these two CSR dimensions. While small, the relationship is positive, implying the possibility to improve financial performance by improving the relationship between the firm and its stakeholders. Further, the link between these two scores is found to be characterized by a lower tail dependency of 0.26 . This suggests that those firms characterized by lower economic performance, relative to best economic performers, usually put higher efforts into defining rules and practices to balance the interests of the different firm stakeholders, such as shareholders, managers, employees, customers, suppliers, creditors, as well as the government and the community. The BB1 Copula also shows an upper tail dependency, but with a negligible magnitude.

The second tree of our C-vine relates environmental with social and governance performance, conditional on the economic outcome. The BB1 copula is found to offer the best fit to describe dependence between environmental and social scores. Consistently with the first tree, firms with better environmental performance are also seen to have remarkable social performance, being the Kendall's $\tau$ for this dependence on the order of 0.41 . The BB1 copula allows for different nonzero lower and upper tail dependence coefficients. Tail dependence estimates refine research findings by suggesting that it is in the lower tail of the distribution when higher efforts to excel in both dimensions are put by corporations. In the upper tail of the distribution, reflecting firms that are already outperforming in both dimensions, the correlation drops to 0.25 . The relationship between governance and environmental dimensions, conditional upon the first tree, is found to be 
very close to zero. The last tree also shows that social and governance ratings have hardly any link. The next section presents policy conclusions from our research results and concludes.

\section{Policy conclusions and concluding remarks}

While the market-based economy has emerged as an efficient mechanism to allocate scarce economic resources, it has also led to unprecedented social tensions and environmental pressures that need to be considered for business sustainability. More recently, given the effect of poor corporate governance on shareholder value, issues such as business ethics have also become part of the investor agenda. The new business paradigm recognizes that long-term sustainable returns depend on well governed social, environmental and economic systems. Changes in the business model have led to changes in firm performance measurement: firm disclosure of environmental, social and corporate governance data has become increasingly common. The relationship between financial performance and other dimensions of CSR has not been well established by the literature. Our article sheds light on this debate by conducting a firm-level study based on a sample of global corporations.

Our analysis is based on ASSET4 ESG dataset in 2012. We identify the empirical regularities characterizing dependence between firm economic, environmental, social and corporate governance using a C-Vine copula model. To our knowledge, this is the first work assessing dependence between all four dimensions of CSR. It is also the first work that adopts a flexible statistical copula approach for such purpose.

Results from copula analysis suggest that our sample firms are integrating sustainability into their business practices, with a rather strong positive relationship between three CSR dimensions: economic, social and environmental. The positive link between economic and 
environmental dimensions suggests that a reduction in resource use and emissions is likely to lead to a decline in production costs and/or a less price-elastic demand. A policy implication of this result is that the business community has been able to make the two performance dimensions complementary rather than substitute. As a result, adoption of environmentally friendly technologies is likely to lead to improved firm financial health. Results are also suggestive that improvements in employment quality, human rights, community, and product responsibility will also bring higher economic profits. These could come through higher employee satisfaction and retention, enhanced firm reputation, less elastic demand, among others. This demands for setting aside much of the old-school labor management practices to embrace new work attitudes and philosophies in order to increase work quality.

In our sample of global firms, and in contrast to environmental and social performance, corporate governance actions don't hold a strong positive relationship with higher economic results. A policy implication is that while governance may help to create a better image for the firm, what really reduces costs and increases consumers' demand and their willingness to pay for the firm's products is effective reduction of pollution and promotion of social welfare.

To summarize, the four main pillars of CSR are positively interconnected, thus showing how improvements in one pillar will lead to improvements in the rest of the pillars. As a result, shareholders should encourage firm managers to pursue a multidimensional CSR objective, which should eventually lead to better financial outcomes. The degree of interdependence is, however, not homogeneous, being high for the cluster comprising economic, social and environmental dimensions.

Our empirical approach is limited by data availability, which did not allow us to characterize the causes underlying the relationship between the four CSR dimensions. Future 
research may seek to understand these causes that may be related to legislation, sector, location, etc. Sectorwise or regionwise analyses will allow a better understanding the concept of CSR. Our analysis is based on global companies that usually show high reputation indices and tend to be socially responsible (Epstein \& Buhovac, 2014). Future research should also consider Small and Medium Sized Enterprises (SMEs), whose performance may significantly differ from the global companies in our sample. 


\section{Acknowledgments}

The authors gratefully acknowledge financial support from Instituto Nacional de

Investigaciones Agrícolas (INIA) from Spain and the European Regional Development Fund

(ERDF), Plan Nacional de Investigación Científica, Desarrollo e Innovación Tecnológica

(I+D+i), Project Reference Number RTA2012-00002-00-00. 


\section{References}

Aas, K., Czado, C., Frigessi, A., \& Bakken, H. (2009). Pair-copula constructions of multiple dependence. Insurance: Mathematics and Economics, 44(2), 182-198. https://doi.org/10.1016/j.insmatheco.2007.02.001

Alafi, K., \& Hasoneh, A. B. (2012). Corporate social responsibility associated with customer satisfaction and financial performance a case study with Housing Banks in Jordan. International Journal of Humanities and Social Science, 2(15), 102-115.

Andreou, P. C., Louca, C., \& Panayides, P. M. (2014). Corporate governance, financial management decisions and firm performance: Evidence from the maritime industry. Transportation Research Part E: Logistics and Transportation Review, 63, 59-78. https://doi.org/10.1016/j.tre.2014.01.005

Azam, M., Usmani, S., \& Abassi, Z. (2011). The impact of corporate governance on firm's performance: Evidence from Oil and Gas Sector of Pakistan. Australian Journal of Basic and Applied Science, 5(12), 2978-2983.

Barnett, M. L., \& Salomon, R. M. (2006). Beyond dichotomy: the curvilinear relationship between social responsibility and financial performance. Strategic Management Journal, 27(11), 1101-1122. https://doi.org/10.1002/smj.557

Barnett, M. L., \& Salomon, R. M. (2012). Does it pay to be really good? addressing the shape of the relationship between social and financial performance. Strategic Management Journal, 33(11), 1304-1320. https://doi.org/10.1002/smj.1980

Baumgartner, R. J. (2014). Managing Corporate Sustainability and CSR: A Conceptual Framework Combining Values, Strategies and Instruments Contributing to Sustainable Development. Corporate Social Responsibility and Environmental Management, 21(5), 258271. https://doi.org/10.1002/csr.1336

Bedford, T., \& Cooke, R. M. (2001). Probability Density Decomposition for Conditionally Dependent Random Variables Modeled by Vines. Annals of Mathematics and Artificial Intelligence, 32(1/4), 245-268. https://doi.org/10.1023/A:1016725902970

Bedford, T., \& Cooke, R. M. (2002). Vines: A New Graphical Model for Dependent Random Variables. The Annals of Statistics, 30, 1031-1068. https://doi.org/10.2307/1558694

Belgorodski, N. (2010). Selecting pair-copula families for regular vines with application to the multivariate analysis of European stock market indices. Master's thesis, Technische 
Universität München.

Bhattacharya, C. B., \& Sen, S. (2003). Consumer-Company Identification: A Framework for Understanding Consumers' Relationships with Companies. Journal of Marketing, 67(2), 7688. https://doi.org/10.1509/jmkg.67.2.76.18609

Brammer, S. J., \& Pavelin, S. (2006). Corporate reputation and social performance: The importance of fit. Journal of Management Studies, 43(3), 435-455.

Brammer, S., \& Millington, A. (2008). Does it pay to be different? An analysis of the relationship between corporate social and financial performance. Strategic Management Journal, 29(12), 1325-1343. https://doi.org/10.1002/smj.714

Brechmann, E. C., Schepsmeier, U., \& others. (2013). Modeling dependence with C-and D-vine copulas: The R-package CDVine. Journal of Statistical Software, 52(3), 1-27.

Brown, L. D., \& Caylor, M. L. (2004). Corporate Governance and Firm Performance. SSRN Electronic Journal. https://doi.org/10.2139/ssrn.586423

Brusseau, J. (2011). The Business Ethics Workshop, v. 1.0. Flat World Knowledge.

Cerin, P., \& Reynisson, S. (2010). The Relationships between Economic, Environmental, Social and Corporate Governance Performance--The Moderating effect of Cultural Belongings of the MSCI 3000 Companies.

Chang, D., \& Kuo, L. R. (2008). The effects of sustainable development on firms' financial performance - an empirical approach. Sustainable Development, 16(6), 365-380. https://doi.org/10.1002/sd.351

Chatterji, A. K., Levine, D. I., \& Toffel, M. W. (2009). How well do social ratings actually measure corporate social responsibility? Journal of Economics \& Management Strategy, 18(1), 125169.

Clarke, K. A. (2007). A simple distribution-free test for nonnested model selection. Political Analysis, 15(3), 347-363.

Collison, D. J., Cobb, G., Power, D. M., \& Stevenson, L. A. (2008). The financial performance of the FTSE4Good indices. Corporate Social Responsibility and Environmental Management, 15(1), 14-28.

Crane, A., Henriques, I., Husted, B. W., \& Matten, D. (2017). Measuring Corporate Social Responsibility and Impact: Enhancing Quantitative Research Design and Methods in Business and Society Research. Business \& Society, 56(6), 787-795. 
https://doi.org/10.1177/0007650317713267

Czado, C., Schepsmeier, U., \& Min, A. (2012). Maximum likelihood estimation of mixed C-vines with application to exchange rates. Statistical Modelling, 12(3), 229-255.

D'amato, A., Henderson, S., \& Florence, S. (2009). Corporate social responsibility and sustainable business. A Guide to Leadership Tasks and Functions, 102. Retrieved from http://www.ccl.org/wp-content/uploads/2015/04/CorporateSocialResponsibility.pdf

Eberl, M., \& Schwaiger, M. (2005). Corporate reputation: disentangling the effects on financial performance. European Journal of Marketing, 39(7/8), 838-854. https://doi.org/10.1108/03090560510601798

Eding, E., \& Scholtens, B. (2017). Corporate Social Responsibility and Shareholder Proposals. Corporate Social Responsibility and Environmental Management. https://doi.org/10.1002/csr.1434

Elfenbein, D. W., \& McManus, B. (2010). A greater price for a greater good? Evidence that consumers pay more for charity-linked products. American Economic Journal: Economic Policy, 2(2), 28-60.

Epstein, M. J., \& Buhovac, A. R. (2014). Making sustainability work: Best practices in managing and measuring corporate social, environmental, and economic impacts. Berrett-Koehler Publishers.

Esteban-Sanchez, P., de la Cuesta-Gonzalez, M., \& Paredes-Gazquez, J. D. (2017). Corporate social performance and its relation with corporate financial performance: International evidence in the banking industry. Journal of Cleaner Production, 162, 1102-1110. https://doi.org/10.1016/j.jclepro.2017.06.127

Ferrero-Ferrero, I., Fernández-Izquierdo, M. Á., \& Muñoz-Torres, M. J. (2015). Integrating sustainability into corporate governance: an empirical study on board diversity. Corporate Social Responsibility and Environmental Management, 22(4), 193-207.

Filbeck, G., Gorman, R., \& Zhao, X. (2009a). The "Best Corporate Citizens": Are They Good for Their Shareholders? Financial Review, 44(2), 239-262. https://doi.org/10.1111/j.15406288.2009.00217.x

Filbeck, G., Gorman, R., \& Zhao, X. (2009b). The "Best Corporate Citizens": Are They Good for Their Shareholders? Financial Review, 44(2), 239-262.

Filbeck, G., Gorman, R., \& Zhao, X. (2013). Are the best of the best better than the rest? The effect 
of multiple rankings on company value. Review of Quantitative Finance and Accounting, 41(4), 695-722. https://doi.org/10.1007/s11156-012-0329-5

Flammer, C. (2015). Does Corporate Social Responsibility Lead to Superior Financial Performance? A Regression Discontinuity Approach. Management Science, 61(11), 25492568. https://doi.org/10.1287/mnsc.2014.2038

Fombrun, C. J. (1996). Reputation, Harvard Business School Press. Boston, MA.

Galbreath, J., \& Shum, P. (2012). Do customer satisfaction and reputation mediate the CSR-FP link? Evidence from Australia. Australian Journal of Management, 37(2), 211-229. https://doi.org/10.1177/0312896211432941

Galema, R., Plantinga, A., \& Scholtens, B. (2008). The stocks at stake: Return and risk in socially responsible investment. Journal of Banking \& Finance, 32(12), 2646-2654. https://doi.org/10.1016/j.jbankfin.2008.06.002

Garcia-Castro, R., Ariño, M. A., \& Canela, M. A. (2010). Does social performance really lead to financial performance? Accounting for endogeneity. Journal of Business Ethics, 92(1), 107126.

Garcia-Gallego, A., \& Georgantzis, N. (2009). Market effects of changes in consumers' social responsibility. Journal of Economics \& Management Strategy, 18(1), 235-262.

Gelbmann, U. (2010). Establishing strategic CSR in SMEs: an Austrian CSR quality seal to substantiate the strategic CSR performance. Sustainable Development, 18(2), 90-98. https://doi.org/10.1002/sd.448

Greening, D. W., \& Turban, D. B. (2000). Corporate Social Performance As a Competitive Advantage in Attracting a Quality Workforce. Business \& Society, 39(3), 254-280. https://doi.org/10.1177/000765030003900302

Griffin, J. J., \& Mahon, J. F. (1997). The Corporate Social Performance and Corporate Financial Performance Debate. Business \& Society, 36(1), 5-31. https://doi.org/10.1177/000765039703600102

Gupta, P., \& Sharma, A. M. (2014). A Study of the Impact of Corporate Governance Practices on Firm Performance in Indian and South Korean Companies. Procedia - Social and Behavioral Sciences, 133, 4-11. https://doi.org/10.1016/j.sbspro.2014.04.163

Hamilton, B. H., \& Nickerson, J. A. (2003). Correcting for endogeneity in strategic management research. Strategic Organization, 1(1), 51-78. 
Horváthová, E. (2010). Does environmental performance affect financial performance? A meta-

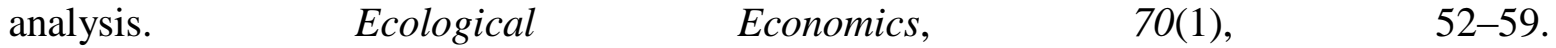
https://doi.org/10.1016/j.ecolecon.2010.04.004

Humphrey, J. E., Lee, D. D., \& Shen, Y. (2012). The independent effects of environmental, social and governance initiatives on the performance of UK firms. Australian Journal of Management, 37(2), 135-151.

Ioannou, I., \& Serafeim, G. (2012). What drives corporate social performance\&quest; The role of nation-level institutions. Journal of International Business Studies, 43(9), 834-864.

Iwata, H., \& Okada, K. (2011). How does environmental performance affect financial performance? Evidence from Japanese manufacturing firms. Ecological Economics, 70(9), 1691-1700. https://doi.org/10.1016/j.ecolecon.2011.05.010

Joe, H. (1996). Families of m-Variate Distributions with Given Margins and m(m-1)/2 Bivariate Dependence Parameters. Lecture Notes-Monograph Series. Institute of Mathematical Statistics. https://doi.org/10.2307/4355888

Joe, H. (1997). Multivariate Models and Multivariate Dependence Concepts. Monographs in statistics and probability, Vol. 73. Chapman and Hall, London.

Kansal, M., Joshi, M., \& Batra, G. S. (2014). Determinants of corporate social responsibility disclosures: Evidence from India. Advances in Accounting, 30(1), 217-229. https://doi.org/10.1016/j.adiac.2014.03.009

Kurowicka, D. and Cooke, R. M. (2004). Distribution - free continuous bayesian belief nets. In Fourth International Conference on Mathematical Methods in Reliability Methodology and Practice, Santa Fe, New Mexico.

Kurowicka, D., \& Cooke, R. (2006). Uncertainty Analysis with High Dimensional Dependence Modelling. Chichester, UK: John Wiley \& Sons, Ltd. https://doi.org/10.1002/0470863072

Lado, A. A., \& Wilson, M. C. (1994). Human resource systems and sustained competitive advantage: A competency-based perspective. Academy of Management Review, 19(4), 699727. https://doi.org/10.5465/AMR.1994.9412190216

Lima Crisóstomo, V., de Souza Freire, F., \& de Vasconcellos, F. (2011). Corporate social responsibility, firm value and financial performance in Brazil. Social Responsibility Journal, 7(2), 295-309.

Lin, C.-H., Yang, H.-L., \& Liou, D.-Y. (2009). The impact of corporate social responsibility on 
financial performance: Evidence from business in Taiwan. Technology in Society, 31(1), 5663. https://doi.org/10.1016/j.techsoc.2008.10.004

López-Gamero, M. D., Molina-Azorín, J. F., \& Claver-Cortés, E. (2009). The whole relationship between environmental variables and firm performance: Competitive advantage and firm resources as mediator variables. Journal of Environmental Management, 90(10), 3110-3121. https://doi.org/10.1016/j.jenvman.2009.05.007

Manasakis, C., Mitrokostas, E., \& Petrakis, E. (2013). Certification of corporate social responsibility activities in oligopolistic markets. Canadian Journal of Economics/Revue Canadienne D'\{é\}conomique, 46(1), 282-309.

Manasakis, C., Mitrokostas, E., \& Petrakis, E. (2014). Strategic Corporate Social Responsibility Activities and Corporate Governance in Imperfectly Competitive Markets. Managerial and Decision Economics, 35(7), 460-473. https://doi.org/10.1002/mde.2635

Margolis, J. D., Elfenbein, H. A., \& Walsh, J. P. (2009). Does it pay to be good... and does it matter? A meta-analysis of the relationship between corporate social and financial performance. https://doi.org/https://papers.ssrn.com/sol3/papers.cfm?abstract_id=1866371

Margolis, J. D., \& Walsh, J. P. (2003). Misery Loves Companies: Rethinking Social Initiatives by Business. Administrative Science Quarterly, 48(2), 268. https://doi.org/10.2307/3556659

Matten, D., \& Crane, A. (2005). Corporate citizenship: Toward an extended theoretical conceptualization. Academy of Management Review, 30(1), 166-179.

Molina-Azorín, J. F., Claver-Cortés, E., López-Gamero, M. D., \& Tarí, J. J. (2009). Green management and financial performance: a literature review. Management Decision, 47(7), 1080-1100. https://doi.org/10.1108/00251740910978313

Moon, J. (2007). The contribution of corporate social responsibility to sustainable development. Sustainable Development, 15(5), 296-306. https://doi.org/10.1002/sd.346

Muhammad, N., Scrimgeour, F., Reddy, K., \& Abidin, S. (2015). The relationship between environmental performance and financial performance in periods of growth and contraction: evidence from Australian publicly listed companies. Journal of Cleaner Production, 102, 324-332. https://doi.org/10.1016/j.jclepro.2015.04.039

Nelsen, R. B. (2006). An introduction to copulas, 2nd. New York: SpringerScience Business Media.

Nollet, J., Filis, G., \& Mitrokostas, E. (2016). Corporate social responsibility and financial 
performance: A non-linear and disaggregated approach. Economic Modelling, 52, 400-407. https://doi.org/10.1016/j.econmod.2015.09.019

Oeyono, J., Samy, M., \& Bampton, R. (2011). An examination of corporate social responsibility and financial performance. Journal of Global Responsibility, 2(1), 100-112. https://doi.org/10.1108/20412561111128555

Patton, A. J. (2004). On the Out-of-Sample Importance of Skewness and Asymmetric Dependence for Asset Allocation. Journal of Financial Econometrics, 2(1), 130-168. https://doi.org/10.1093/jjfinec/nbh006

Patton, A. J. (2006). Modelling asymmetric exchange rate dependence. International Economic Review, 47(2), 527-556. https://doi.org/10.1111/j.1468-2354.2006.00387.x

Perrini, F., \& Tencati, A. (2006). Sustainability and stakeholder management: the need for new corporate performance evaluation and reporting systems. Business Strategy and the Environment, 15(5), 296-308. https://doi.org/10.1002/bse.538

Rivera, J. M., Muñoz, M. J., \& Moneva, J. M. (2017). Revisiting the Relationship Between Corporate Stakeholder Commitment and Social and Financial Performance. Sustainable Development. https://doi.org/10.1002/sd.1664

Roberts, P. W., \& Dowling, G. R. (2002). Corporate reputation and sustained superior financial performance. Strategic Management Journal, 23(12), 1077-1093. https://doi.org/10.1002/smj.274

Schäfer, H., Beer, J., Zenker, J., \& Fernandes, P. (2006). Who is who in Corporate Social Responsibility Rating? A survey of internationally established rating systems that measure Corporate Responsibility. Bertelsmann Foundation.

Shah, K. U., Arjoon, S., \& Rambocas, M. (2016). Aligning Corporate Social Responsibility with Green Economy Development Pathways in Developing Countries. Sustainable Development, 24(4), 237-253. https://doi.org/10.1002/sd.1625

Sklar, M. (1959). Fonctions de répartition à n dimensions et leurs marges. Publications de l'Institut de Statistique de l'Université de Paris, 8, 229-231.

Smith, M., Yahya, K., \& Marzuki Amiruddin, A. (2007). Environmental disclosure and performance reporting in Malaysia. Asian Review of Accounting, 15(2), 185-199. https://doi.org/10.1108/13217340710823387

Soana, M.-G. (2011). The Relationship Between Corporate Social Performance and Corporate 
Financial Performance in the Banking Sector. Journal of Business Ethics, 104(1), 133-148. https://doi.org/10.1007/s10551-011-0894-x

Starks, L. T. (2009). EFA Keynote Speech: "Corporate Governance and Corporate Social Responsibility: What Do Investors Care about? What Should Investors Care about?" Financial Review, 44(4), 461-468. https://doi.org/10.1111/j.1540-6288.2009.00225.x

Statman, M., \& Glushkov, D. (2009). The Wages of Social Responsibility. Financial Analysts Journal, 65(4), 33-46. https://doi.org/10.2469/faj.v65.n4.5

Stewart, H., \& Gapp, R. (2014). Achieving Effective Sustainable Management: A Small-Medium Enterprise Case Study. Corporate Social Responsibility and Environmental Management, 21(1), 52-64. https://doi.org/10.1002/csr.1305

Teoh, H. Y., Pin, F. W., Joo, T. T., \& Ling, Y. Y. (1998). Environmental disclosures-financial performance link: Further evidence from industrialising economy perspective. In APIRA 98 Conference, Paper. Osaka, Japan.

Teoh, S. H., Welch, I., \& Wazzan, C. P. (1999). The Effect of Socially Activist Investment Policies on the Financial Markets: Evidence from the South African Boycott. The Journal of Business, 72(1), 35-89. https://doi.org/10.1086/209602

Thomson Reuters. (2013). Thomson Reuters Corporate Responsibility Ratings. Retrieved from http://thomsonreuters.com/content/dam/openweb/documents/pdf/tr-comfinancial/methodology/corporate-responsibility-ratings.pdf

UNIDO. (2015). What is CSR? Retrieved August 8, 2017, from http://www.unido.org/csr/o72054.html

Van Beurden, P., \& Gössling, T. (2008). The worth of values--a literature review on the relation between corporate social and financial performance. Journal of Business Ethics, 82(2), 407424.

Veronica Siregar, S., \& Bachtiar, Y. (2010). Corporate social reporting: empirical evidence from Indonesia Stock Exchange. International Journal of Islamic and Middle Eastern Finance and Management, 3(3), 241-252. https://doi.org/10.1108/17538391011072435

Vogel, D. J. (2005). Is there a market for virtue? The business case for corporate social responsibility. California Management Review, 47(4), 19-45.

Vuong, Q. H. (1989). Likelihood Ratio Tests for Model Selection and Non-Nested Hypotheses. Econometrica, 57(2), 307. https://doi.org/10.2307/1912557 
Waddock, S. A., \& Graves, S. B. (1997). The corporate social performance-financial performance link. Strategic Management Journal, 18(4), 303-319.

Wagner, M., Van Phu, N., Azomahou, T., \& Wehrmeyer, W. (2002). The relationship between the environmental and economic performance of firms: an empirical analysis of the European paper industry. Corporate Social Responsibility and Environmental Management, 9(3), 133146. https://doi.org/10.1002/csr.22

Walley, N., \& Whitehead, B. (1994). It's not easy being green. Harvard Business Review, 72(3), $46-52$.

Wang, Q., Dou, J., \& Jia, S. (2016). A Meta-Analytic Review of Corporate Social Responsibility and Corporate Financial Performance. Business \& Society, 55(8), 1083-1121. https://doi.org/10.1177/0007650315584317

Wright, P., \& Ferris, S. P. (1997). Agency Conflict and Corporate Strategy: The Effect of Divestment on Corporate Value. Strategic Management Journal, 18, 77-83. https://doi.org/10.2307/3088196

Ziegler, A., Busch, T., \& Hoffmann, V. H. (2009). Corporate responses to climate change and financial performance: The impact of climate policy.

Zimmer, D. M. (2015). Analyzing comovements in housing prices using vine copulas. Economic Inquiry, 53(2), 1156-1169. https://doi.org/10.1111/ecin.12156 
Table 1. Bivariate copula families considered and their properties.

\begin{tabular}{llllllll}
\hline & Gaussian & T-copula & Clayton & Gumbel & Frank & BB1 & BB7 \\
\hline Positive dependence & $\mathrm{X}$ & $\mathrm{X}$ & $\mathrm{X}$ & $\mathrm{X}$ & $\mathrm{X}$ & $\mathrm{X}$ & $\mathrm{X}$ \\
Negative dependence & $\mathrm{X}$ & $\mathrm{X}$ & $\cdot$ & $\cdot$ & $\mathrm{X}$ & & $\cdot$ \\
Tail Asymmetry & $\cdot$ & $\cdot$ & $\mathrm{X}$ & $\mathrm{X}$ & $\cdot$ & $\mathrm{X}$ & $\mathrm{X}$ \\
Lower tail dependence & $\cdot$ & $\mathrm{X}$ & $\mathrm{X}$ & $\cdot$ & $\cdot$ & $\mathrm{X}$ & $\mathrm{X}$ \\
Upper tail dependence & $\cdot$ & $\mathrm{X}$ & $\cdot$ & $\mathrm{X}$ & $\cdot$ & $\mathrm{X}$ & $\mathrm{X}$ \\
\hline
\end{tabular}

Table 2. Descriptive Statistics of ESG data

\begin{tabular}{|c|c|c|c|c|}
\hline & GOV Score & ECN Score & ENV Score & SOC Score \\
\hline Mean & 55.30 & 49.86 & 57.75 & 57.01 \\
\hline Std. Dev. & 29.95 & 30.57 & 31.39 & 31.05 \\
\hline Min & 1.39 & 1.09 & 8.59 & 3.66 \\
\hline Max & 96.86 & 98.85 & 94.21 & 97.39 \\
\hline Skewness & -0.46 & 0.001 & -0.33 & -0.33 \\
\hline Kurtosis & -1.18 & -1.37 & -1.49 & -1.37 \\
\hline Jarque Bera test & $256.18^{*}$ & $213.47^{*}$ & $304.42 *$ & $265.50^{*}$ \\
\hline Kolmogorov Smirnov test & $0.11^{*}$ & $0.08^{*}$ & $0.14^{*}$ & $0.12^{*}$ \\
\hline
\end{tabular}

Table 3. A distribution of firms across sectors (by numbers \& percentages)

\begin{tabular}{|c|c|c|c|c|c|c|c|c|c|c|c|c|}
\hline & & $\begin{array}{l}\text { All } \\
\text { Sectors }\end{array}$ & Financial & Industrial & $\begin{array}{l}\text { Consumer } \\
\text { Cyclicals }\end{array}$ & $\begin{array}{l}\text { Basic } \\
\text { Materials }\end{array}$ & $\begin{array}{l}\text { Consumer } \\
\text { Non } \\
\text { Cyclicals }\end{array}$ & Technology & Energy & Healthcare & Utilities & Telecom. \\
\hline Firms & $\mathrm{N}^{\circ}$ & 2728 & 514 & 484 & 423 & 369 & 219 & 206 & 200 & 126 & 110 & 77 \\
\hline $\begin{array}{l}\text { By } \\
\text { sectors }\end{array}$ & $\%$ & $100 \%$ & $19 \%$ & $18 \%$ & $16 \%$ & $14 \%$ & $8 \%$ & $8 \%$ & $7 \%$ & $5 \%$ & $4 \%$ & $3 \%$ \\
\hline
\end{tabular}


Table 4. ML estimate for C-Vine copula \& corresponding Kendall's $\tau$ value for each pair-copula.

\begin{tabular}{llllllll}
\hline Tree & Pair-copula & copula & par1 & par2 & $\lambda_{U}$ & \multicolumn{2}{c}{$\lambda_{L}$} \\
\hline 1 & ECN, ENV & Frank & 4.54 & - & 0 & 0 & 0.42 \\
1 & ECN, SOC & Frank & 5.86 & - & 0 & 0 & 0.50 \\
1 & ECN, GOV & BB1 & 0.48 & 1.06 & 0.08 & 0.26 & 0.24 \\
2 & ENV, SOC |ECN & BB1 & 0.65 & 1.25 & 0.25 & 0.41 & 0.41 \\
2 & ENV, GOV |ECN & Gumbel & 1.06 & - & 0.07 & 0 & 0.06 \\
3 & SOC, GOV |ECN, ENV & BB1 & 0.2 & 1 & 0 & 0.03 & 0.09 \\
\hline
\end{tabular}


Table 5. Vine copula ordering tests

\begin{tabular}{|c|c|c|c|c|c|c|}
\hline Model & & $\begin{array}{l}\text { M2 } \\
\text { ECN- } \\
\text { SOC- } \\
\text { ENV- } \\
\text { GOV }\end{array}$ & $\begin{array}{l}\text { M3 } \\
\text { ECN- } \\
\text { ENV- } \\
\text { GOV- } \\
\text { SOC }\end{array}$ & $\begin{array}{l}\text { M4 } \\
\text { ECN- } \\
\text { SOC- } \\
\text { GOV- } \\
\text { ENV }\end{array}$ & $\begin{array}{l}\text { M5 } \\
\text { ECN- } \\
\text { GOV- } \\
\text { ENV- } \\
\text { SOC }\end{array}$ & $\begin{array}{l}\text { M6 } \\
\text { ECN- } \\
\text { GOV- } \\
\text { SOC- } \\
\text { ENV }\end{array}$ \\
\hline \multirow{6}{*}{$\begin{array}{l}\text { M1 } \\
\text { ECN- } \\
\text { ENV- } \\
\text { SOC- } \\
\text { GOV- }\end{array}$} & Vuong Statistic & 2.09 & 0 & 2.09 & 1.83 & 1.83 \\
\hline & P-value & 0.0 & 1.00 & 0.03 & 0.06 & 0.06 \\
\hline & Decision & $\mathrm{M} 1>\mathrm{M} 2$ & $\mathrm{M} 1=\mathrm{M} 3$ & $\mathrm{M} 1>\mathrm{M} 4$ & $\mathrm{M} 1=\mathrm{M} 5$ & $\mathrm{M} 1=\mathrm{M} 6$ \\
\hline & Clarke Statistic & 1472 & 411 & 1472 & 1531 & 1531 \\
\hline & P-value & 0,00 & 0,00 & 0,00 & 0,00 & 0,00 \\
\hline & Decision & $\mathrm{M} 1>\mathrm{M} 2$ & $\mathrm{M} 3>\mathrm{M} 1$ & M1>M4 & M1>M5 & M1>M6 \\
\hline
\end{tabular}


Table 6. Goodness-of-fit test scores for the bivariates Copula

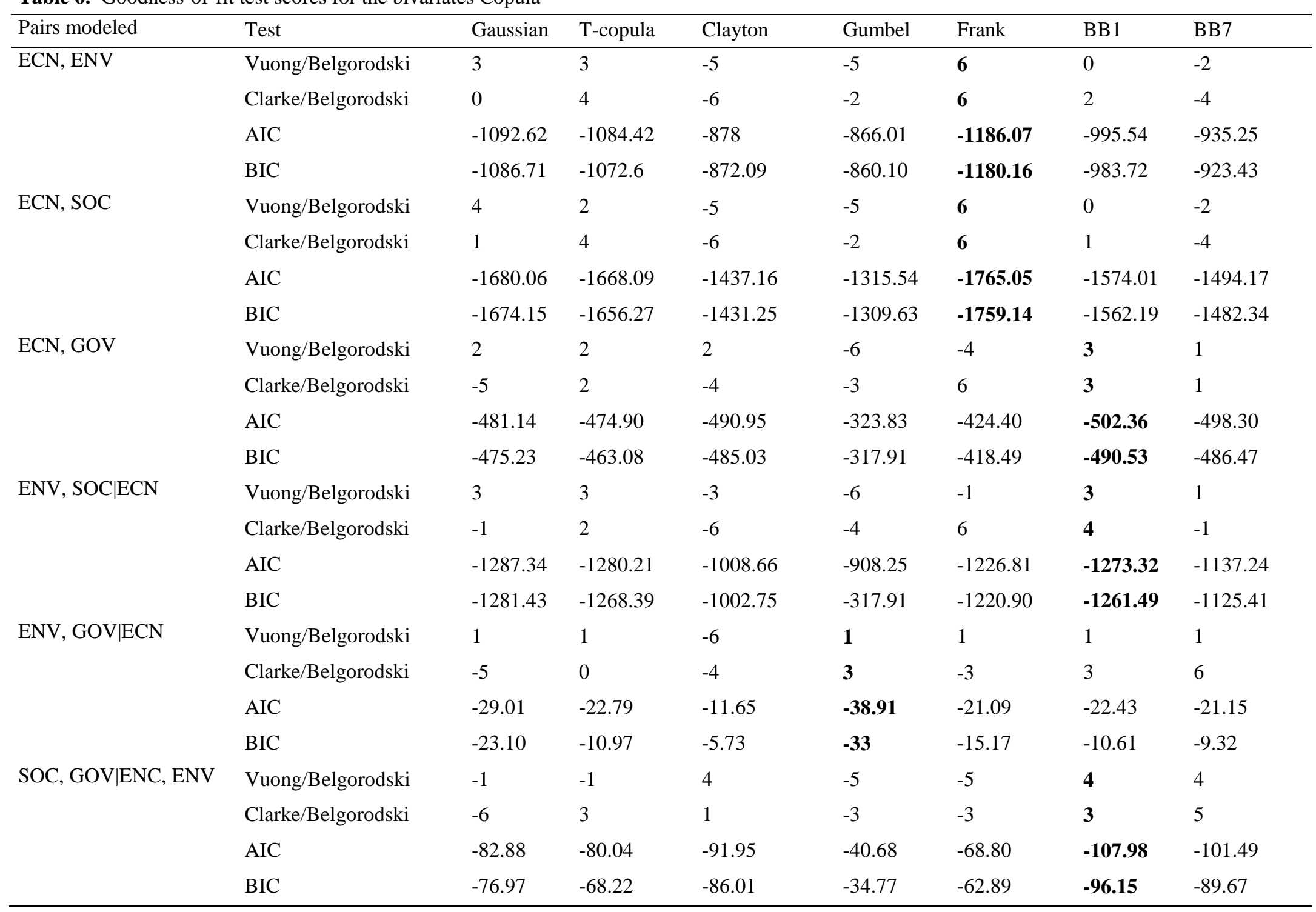




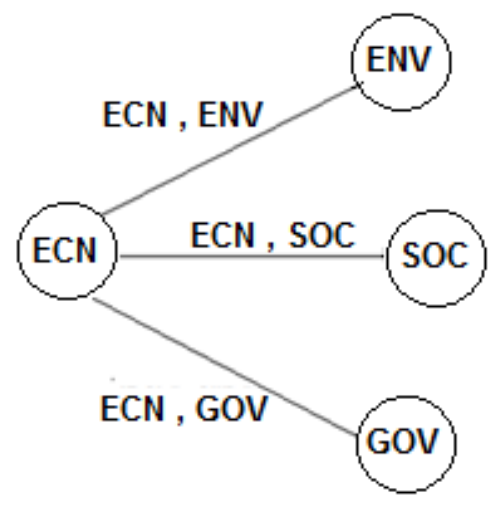

$T_{1}$

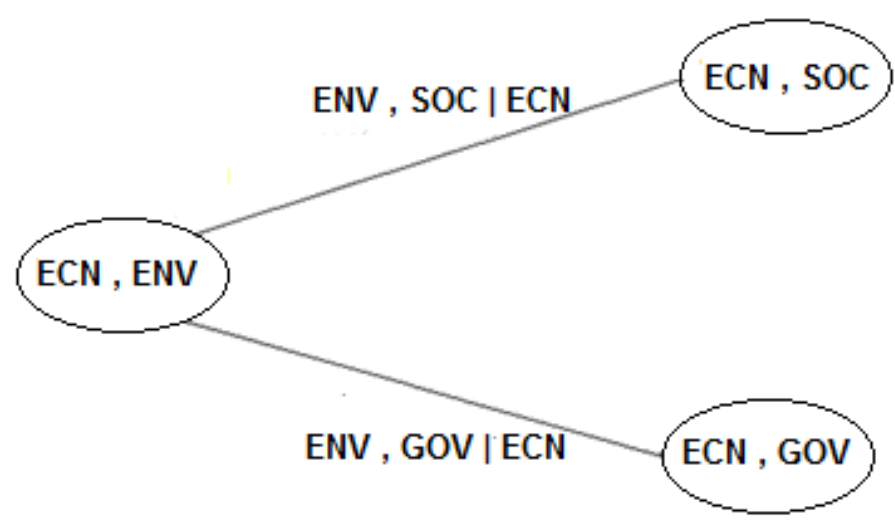

$\mathrm{T}_{2}$

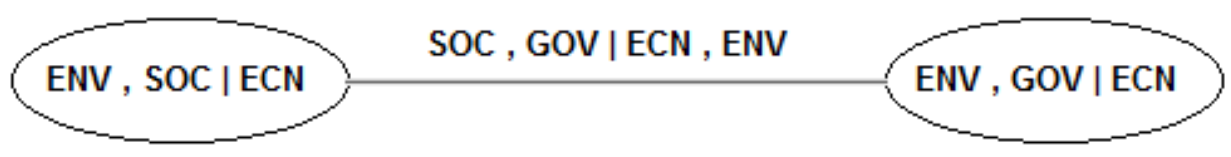

$T_{3}$

Figure 1. C-Vine copula with four firm performance indicators 


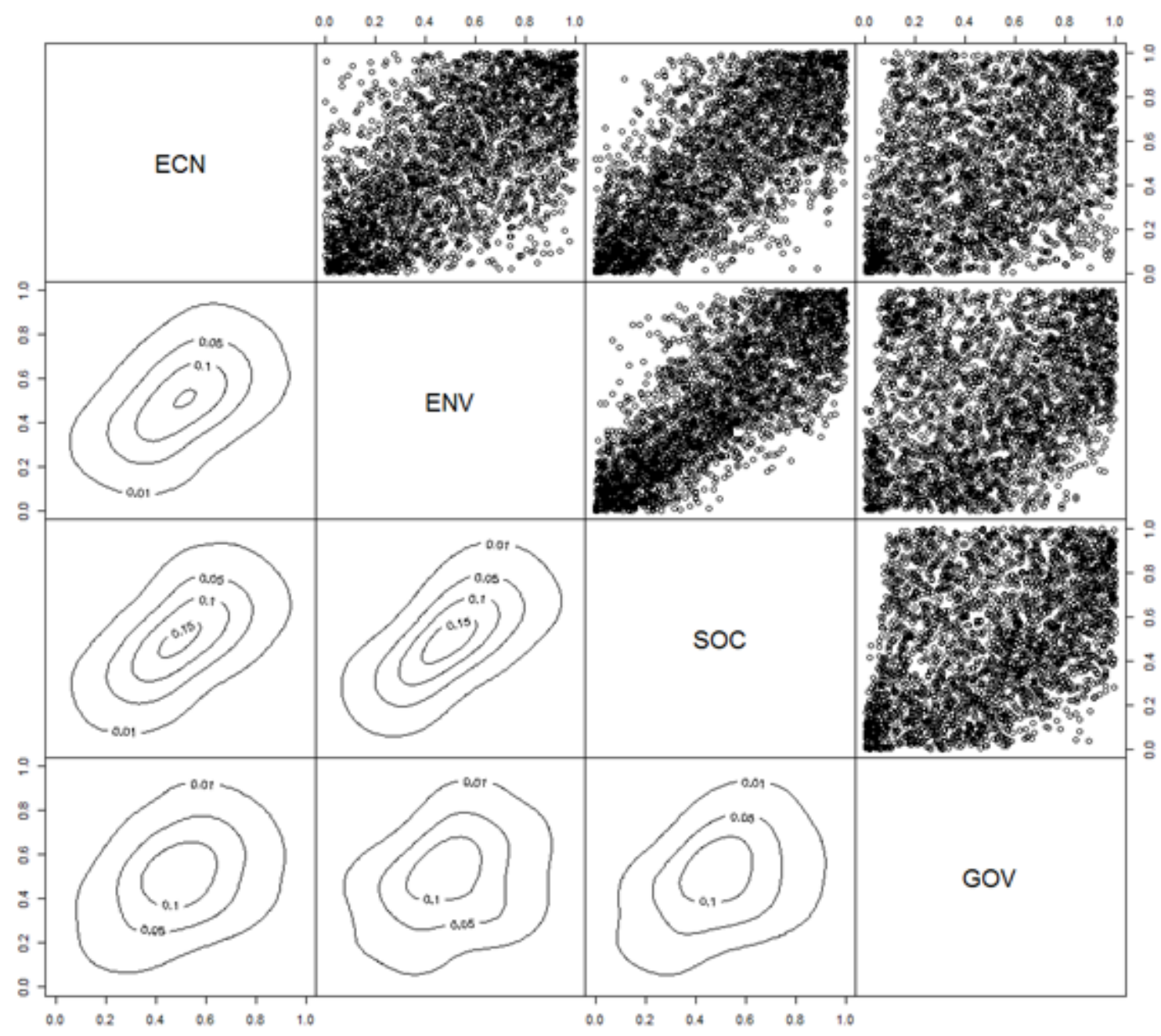

Figure 2. Pairs plot of the ESG data set with scatter plots above and contour plots with standard normal margins below the diagonal. 